\title{
“In-house" preparation of "99m-Tc-EDDA/HYNIC-TOC, a specific targeting agent for somatostatin receptor scintigraphy
}

\author{
Sonja Kuzmanovska*, Olivija Vaskova, Marina Zdraveska Kocovska \\ Institute of Pathophysiology and Nuclear Medicine, Medical Faculty, University "Sts Cyril and Methodius", Vodnjanska \\ 17, Skopje, Republic of Macedonia,
}

Received: November 2011; Accepted: January 2012

\begin{abstract}
The use of radiolabeled peptide ligands as diagnostics and therapeutics in nuclear oncology has increased recently. One of the most frequently used radiopharmaceutical is ${ }^{99 \mathrm{~m}} \mathrm{Tc}-\mathrm{EDDA} / \mathrm{HYNIC}-\mathrm{TOC}$, a somatostatin analog with affinity for certain types of somatostatin receptors, overexpressed in tumors of neuroendocrine origin. The radiopharmaceutical is not readily available; therefore we introduced its "in house" preparation within project activities supported by the International Atomic Energy Agency (IAEA). We optimized the radiolabeling protocol, prepared a small batch of frozen kits, performed ITLC quality control and animal biodistribution during the preclinical evaluation procedures. The co-ligand exchange labeling procedure was carried out at $100^{\circ} \mathrm{C}$ during $10 \mathrm{~min}$, resulting in radiochemical purity $>90 \%$. The biodistribution scintigrams in normal Wistar rats showed rapid blood clearance after 15 min and predominant kidney accumulation after $4 \mathrm{~h}$, in accordance with the data reported by other authors. Storage stability of the formulated small batch frozen kit $\left(-20^{\circ} \mathrm{C}\right)$ was evaluated within 6 months, with radiolabeling yield ranging between $94,3 \%$ and $96,9 \%$. We conclude that frozen kit can be a safe alternative to the freeze-dried for small batch in house production, and after the satisfactory preclinical evaluation, the "in house" prepared ${ }^{99 \mathrm{~m}} \mathrm{Tc}-\mathrm{EDDA} /$ HYNIC-TOC can be introduced in clinical practice as specific targeting agent for somatostatin receptor scintigraphy.
\end{abstract}

Key words: radiopharmaceutical, technetium- $99 \mathrm{~m}, \mathrm{tyr}^{3}$-octreotide, receptor scintigraphy, in house production, quality control

\section{Introduction}

The development of Nuclear Medicine towards molecular diagnostic imaging modality in the past two decades was followed by intensive research and applicative work resulting with introduction of wide variety of new generation radiopharmaceuticals. Labeled peptides have proven their potential as targeting agents for receptor scintigraphy, especially the synthetic analogs with preferable biological half-life and in vivo stability. Octreotide, a somatostatin analog, was used to compound ${ }^{111}$ In-DTPA-octreotide (OctreoScan), the first commercial radiolabeled peptide, regulatory approved in Europe and USA for clinical application. It became the imaging agent of choice for detection of

\footnotetext{
* skuzmanovska@gmail.com, +3892 3112831, fax: +38923147203
}

somatostatin (SST) receptors, overexpressed in neuroendocrine tumors (NET), with evidence of higher sensitivity in comparison with CT and MR scanning (Shi et al., 1998). Besides the specific somatostatin receptor imaging properties, somatostatin receptor scintigraphy can be used as tumor staging agent (Lebtahi et al., 1997), as well as a predictor of the effectiveness of therapy with somatostatin analogues (Krenning et al., 1993). Despite of the favorable features, ${ }^{111}$ In-DTPA-octreotide has limited availability, suboptimal imaging gamma energy and high cost. Therefore, efforts were made by different research groups worldwide to replace the radiometal ${ }^{111} \mathrm{In}$ with ${ }^{99 \mathrm{~m}} \mathrm{Tc}$, the most preferable imaging radionuclide for single photon emission computed scintigraphy (SPECT) up to date (Maina et al., 1995; Vallabhajosula et al.,1996; Decristoforo et al.,2000).

Peptide labeling with ${ }^{99 \mathrm{~m}}$ Tc-pertechnetate is however a complex task and considering the small size of peptide 
molecules and limited number of donor atoms, the indirect labeling approach is shown to be the most preferable technique (Liu et al., 1997). Thus, a bifunctional chelator is used to conjugate the peptide molecule and simultaneously form a coordination bound with the reduced ${ }^{99 \mathrm{~m}} \mathrm{Tc}-$ pertechnetate. One of the earliest efficient labeling methods was reported by Maecke (Maecke and Béhé, 1996) and later developed by Decristoforo (Decristoforo and Mather, 1999). They used $\mathrm{Tyr}^{3}$ octreotide (TOC) conjugated with HYNIC (hydrazinonicotic acid) as a bifunctional chelator. When using HYNIC as a bifunctional chelator, the complex has to be stabilized through the addition of a co-ligand or a mixture of co- ligands. To stabilize the ${ }^{99 \mathrm{~m}} \mathrm{Tc}$ - HYNICTOC complex, EDDA (ethylendiamine N, N' diacetic acid) was used as co-ligand, resulting with favorable biodistribution, low blood levels and high renal excretion of the radiopharmaceutical.

Since ${ }^{99 m}$ Tc-EDDA/HYNIC-TOC was evidenced to be an efficient tool for detecting SST2 and SST5 receptor subtypes, the main targets for the somatostatin receptor scintigraphy are carcinoids, insulinomas, pituitary adenoma, pheochromocytoma, neuroblastoma, medulary thyroid carcinoma. The radiopharmaceutical is not readily available, therefore our goal was to introduce it as "in house" product within the project activities supported by the International Atomic Energy Agency (IAEA), for updating and expanding the range of nuclear oncology services provided by our institute.

\section{Material and methods}

- Chemicals with high purity grade were purchased by Merck, Germany $\left(\mathrm{SnCl}_{2} \cdot 2 \mathrm{H}_{2} \mathrm{O}\right)$, or granted by IAEA (EDDA from Fluka Chemie Gmbh, Tricine from SigmaAldrich Chemie Gmbh).

- The peptide conjugate (HYNIC-TOC) was provided by Radioisotope Centre POLATOM, Poland

${ }^{-99 m} \mathrm{Tc}$-pertechetate was obtained as fresh eluate from commercial ${ }^{99} \mathrm{Mo} /{ }^{199 m} \mathrm{Tc}$ generator (ELUMATIC-III) supplied by Cis biointernational, France

- For the product purification SepPak C-18 mini cartridges (Waters, Milford, USA) were used, and for the final sterilization of the radiopharmaceutical $0,20 \mu$ sterile Millipore filters

- For the quality control TLC-SG (Merck, 5553 Silica gel 60) aluminum sheets were used

- Biodistribution studies were performed on normal female Wistar rats in accordance with EC Directive 86/609/ EEC for animal experiments

\section{Preparation of the radiopharmaceutical}

In order to optimize the radiopharmaceutical production protocol concerning own facilities two approaches were implemented:

1. Production of a single dose wet labeled ${ }^{99 \mathrm{~m}} \mathrm{Tc}-\mathrm{ED}-$

\section{DA/HYNIC-TOC}

2. Production of a small-batch frozen kits for labeling with ${ }^{99 \mathrm{~m}} \mathrm{Tc}$-pertechnetate

The optimized labeling conditions $(\mathrm{pH}$, temperature, reaction time, specific activity) applied during the wet labeling procedure were identical during the labeling of frozen kits.

Wet labeling protocol was conducted according the publication of Decristoforo (Decristoforo and Mather, 1999), via co-ligand exchange as follows: in a sterile glass vial $20 \mu \mathrm{g}$ of HYNIC-TOC were mixed with $1 \mathrm{~mL}$ of solution mixture (1:1) consisting of $20 \mathrm{mg}$ EDDA and 10 $\mathrm{mg}$ tricine, $15 \mu \mathrm{g}$ of $\mathrm{SnCl}_{2} \cdot 2 \mathrm{H}_{2} \mathrm{O}$ dissolved in $0,1 \mathrm{M} \mathrm{NCl}$ and incubated with addition of $1000 \mathrm{MBq} 99 \mathrm{mTc}-$ pertechnetate (up to final volume of $2 \mathrm{~mL}$ ) in water bath at 70 ${ }^{\circ} \mathrm{C}$ for 30 minutes (protocol 1). The solutions were freshly prepared and purged with sterile nitrogen. To optimize the reaction time we followed the von Guggenberg (von Guggenberg et al., 2003) modification of the previous labeling protocol and heated the reaction mixture at $100{ }^{\circ} \mathrm{C}$ for 10 minutes (protocol 2). The $\mathrm{pH}$ of the labeled product was 7 ( measured semi-quantitative by Merck pH- indicator strips). Finally, the radiopharmaceutical was SepPak purified and sterile filtered.

Kit formulation was prepared for a mini batch of 12 vials. We modified the protocol published for freeze-dried kit formulation by von Guggenberg (von Guggenberg et al.,2004). Initially, $150 \mathrm{mg}$ of EDDA and $300 \mathrm{mg}$ of tricine were dissolved in $14 \mathrm{~mL}$ sterile $\mathrm{H}_{2} \mathrm{O}$ (in a vial) by heating in water bath. $12 \mathrm{~mL}$ of the co-ligand mixture were transferred into $50 \mathrm{ml}$ sterile evacuated closed vial trough 0,20 $\mu$ Millipore filter. $250 \mu \mathrm{L}(1 \mathrm{mg} / \mathrm{mL})$ of HYNIC-TOC solution was added with syringe in the vial and mixed. Finally, $150 \mu \mathrm{L}$ of instant dilution of $\mathrm{SnCl}_{2} \times 2 \mathrm{H}_{2} \mathrm{O}$ in $0,1 \mathrm{M} \mathrm{HCl}$ consisting $240 \mu \mathrm{g}$ was injected and mixed properly. The $\mathrm{pH}$ of this solution was 4 . Finally, the solution was dispensed in 12 sterile evacuated vials trough Millipore GV (low protein binding) filter in $1 \mathrm{~mL}$ volume. The vials were filled with sterile nitrogen and stored frozen at $-20{ }^{\circ} \mathrm{C}$.

The labeling procedure of the frozen kit was performed after thawing at room temperature, adding $0,5 \mathrm{~mL}$ of $0,2 \mathrm{~N}$ Phosphate buffer and $0,5 \mathrm{~mL}$ of ${ }^{99 \mathrm{~m}} \mathrm{Tc}$-pertechnetate. The mixture was incubated for 10 minutes in boiling water bath. The final $\mathrm{pH}$ was 7 . The radiopharmaceutical was SepPak purified and sterile filtered.

\section{SepPak purification procedure}

A SepPak C-18 mini cartridge was initially activated with $5 \mathrm{~mL}$ of $100 \%$ ethanol, washed with $5 \mathrm{~mL}$ of $0.9 \%$ saline and dried with $5 \mathrm{~mL}$ of air. The radiolabeled solution was passed through the cartridge which was washed afterwards with $5 \mathrm{~mL}$ of saline. The labeled peptide was eluted from the cartridge with $0.6 \mathrm{~mL}$ of $80 \%$ ethanol through a low-protein binding sterile filter, and finally diluted with $5 \mathrm{~mL}$ of saline. The content of the ethanol in the final solution was not likely to induce side effects. 


\section{Quality Control}

\section{Radiochemical purity}

Instant thin -layer chromatography (ITLC) was performed on Silica gel strips with different mobile phases: Methylethylketone (MEK) to determine the percentage of

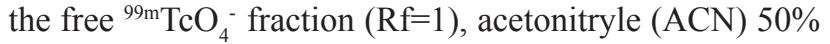
for the ${ }^{99 \mathrm{~m}} \mathrm{Tc}$-colloid fraction $(\mathrm{Rf}=0)$. For the non-peptide bound ${ }^{99 \mathrm{~m}} \mathrm{Tc}$-co- ligand $0.1 \mathrm{M}$ Sodium citrate buffer $(\mathrm{pH}=5)$ $(\mathrm{Rf}=1)$ and optionally $0.9 \% \mathrm{NaCl}(\mathrm{Rf}=1)$ was used. Radiochemical purity was calculated by supstraction the sum of the impurities from $100 \%$. Radiochromatograms were obtained by Veenstra Radiochromatogram scanner VCS 101, with a software package.

\section{Sterility}

The small-batch of frozen kits was tested on sterility, in compliance with the internal GMP Production Protokol.

\section{Biodistribution}

For biodistribution studies $7,4 \mathrm{MBq}$ of the radiopharmaceutical (consisting 1-2 $\mu \mathrm{g}$ of peptide) in a volume of $300 \mu \mathrm{L}$ was injected into the tail vein of the rats. Animal scintigrams were obtained after 15, $60 \mathrm{~min}, 2 \mathrm{~h}$ and $4 \mathrm{~h}$ p.i. in a supine position, with a single-head Simens (e.cam) gamma camera, using a pinhole collimator. Biodistribution within the organs was performed $4 \mathrm{~h}$ p.i.; blood sample was collected with heparinized syringe by heart puncture, the animals were sacrificed afterwards and other organs of interest (liver, kidneys, spleen, pancreas, adrenals, gut and muscle) extracted. The organs were weighed and radioactivity measured respectively in well-type gamma scintillation counter. The results were expressed as percentage of the injected dose per gram of the organ $(\% \mathrm{ID} / \mathrm{g})$.

\section{Results and Discussion}

For the optimization of the labeling protocol, the radiochemical impurities obtained by ITLC-SG for the different wet labeling protocols were displayed (Table 1) and compared.

The proportion of free pertechnetate was low $(0,53 \%$ for protocol 1 and $0,36 \%$ for protocol 2) as well as the ${ }^{99 \mathrm{~m}}$ Tc-coloid impurities (3.4\% and $2.46 \%$ respectively). Although the results for the radiochemical impurities were similar in both protocols, the $10 \mathrm{~min}$. boiling water (protocol 2) was chosen as more convenient, as suggested by von
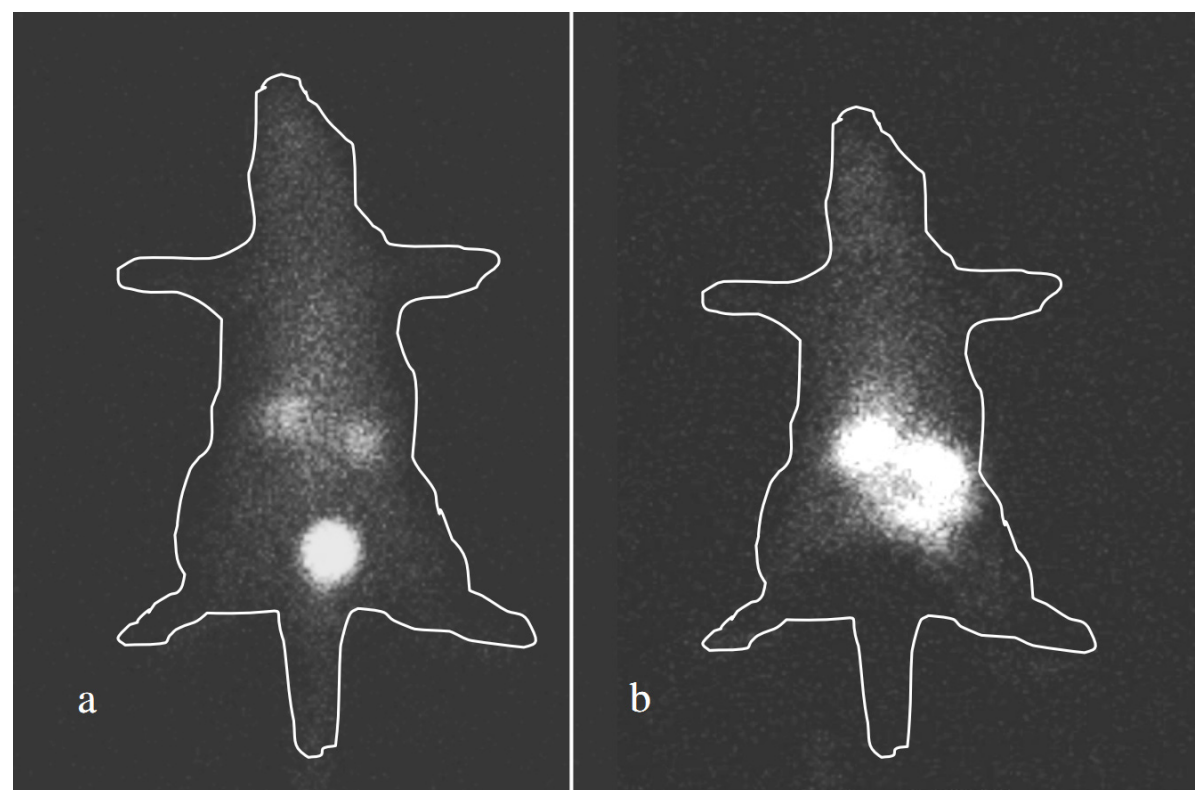

Fig. 1. Gamma camera images of ${ }^{99 \mathrm{~m}} \mathrm{Tc}-\mathrm{EDDA} / \mathrm{HYNIC}-\mathrm{TOC}$ a) $15 \mathrm{~min}$ and b) $4 \mathrm{~h}$ post injection into normal Wistar rats

Table 1. Labeling conditions and radiochemical impurity of the wet labeled ${ }^{99 m}$ Tc-EDDA/HYNIC-TOC

Radiochemical impurity (mean $\% \pm \mathrm{SD}) \mathrm{n}=3$

\begin{tabular}{cccc} 
Labeling conditions & $\begin{array}{c}{ }^{99 \mathrm{~m}} \mathrm{TcO} 4 \\
(\mathrm{MEK})\end{array}$ & $\begin{array}{c}{ }^{99 \mathrm{~m} T c-R H} \\
(\mathrm{ACN} \mathrm{50 \%})\end{array}$ & $\begin{array}{c}{ }^{99 \mathrm{~m} T c-n o n} \text { peptide bound } \\
\text { (0.1N Citrate buff. })\end{array}$ \\
\hline $70^{\circ} \mathrm{C}, 30 \mathrm{~min}$. & $0.53 \pm 0.15$ & $3.4 \pm 0.72$ & $5.4 \pm 0.82$ \\
$100^{\circ} \mathrm{C}, 10 \mathrm{~min}$. & $0.36 \pm 0.11$ & $2.46 \pm 0.76$ & $5.63 \pm 1.5$ \\
\hline
\end{tabular}

Макед. фарм. билт., $57(1,2) 65$ - 70 (2011) 
Guggenberg et al (2003). The percentage of the overall radiolabeled impurities was less than $10 \%$, accepted as upper limit and reported by other authors (Plachcinska et al., 2003; von Guggenberg et al., 2004; Melero et al., 2009). For the assessment of non-peptide bound impurities $0.9 \%$ $\mathrm{NaCl}$ was used elsewhere (Bangard et al. 2000; Plachcins$\mathrm{ka}$ et al.2004). We obtained lower percentage for the above mentioned impurities with $0.9 \% \mathrm{NaCl}(2.8 \% \pm 1.06)$ compared to $0.1 \mathrm{M}$ Citrate buffer mobile phase. For more precise detection of peptide related side products, HPLC analysis with radiation detector would be preferable method, but it was not available in our laboratory during this study.

Animal biodistribution studies, integrated in our quality control protocol, were carried out with wet labeled kits. The results from the imaging study are presented in Fig. 1.

The radiopharmaceutical was cleared rapidly from the blood, as shown on the 15 min static image, and the most intense radioactivity was observed in the kidneys and bladder. The late, $4 \mathrm{~h}$ image confirmed the predominant renal uptake, as reported by Decristoforo et al. (1999). The proportion of the injected dose/g in the kidneys was 2, 95\% (see Fig. 2), and with lesser extent in the gut $(1,16 \%)$ and the liver $(1,15 \%)$. No activity was observed in the thyroid, which was in accordance with the low percentage of free ${ }^{99 \mathrm{~m}} \mathrm{Tc}$-petrechnetate impurity found by ITLC-SG quality control.

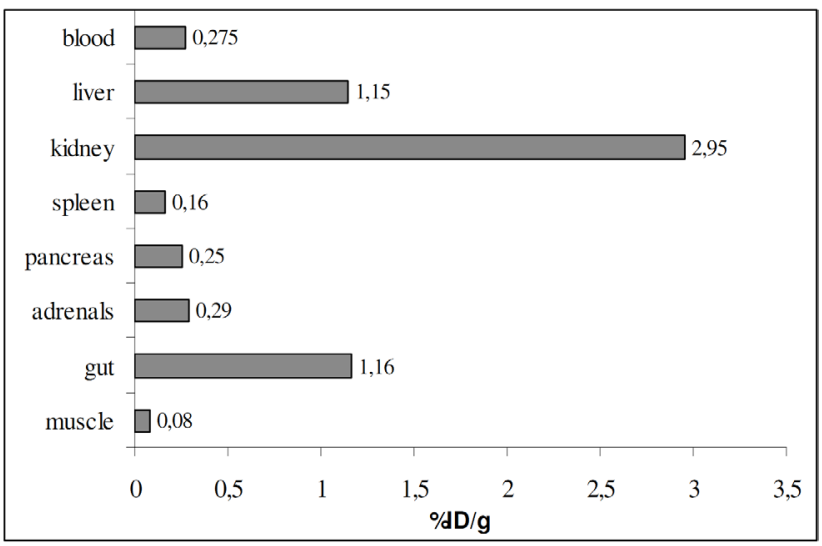

Fig. 2. Biodistribution of ${ }^{99 \mathrm{~m} T c-E D D A} / \mathrm{HYNIC}-\mathrm{TOC}$ in normal Wistar rats $4 \mathrm{~h}$ p.i $(\mathrm{n}=2)$

Although the wet labeling protocol was confirmed as efficient and reliable procedure for ${ }^{99 \mathrm{~m}} \mathrm{Tc}$ labeling of / HYNIC-TOC, it was more time and labor consuming in comparison with frozen kit labeling. Therefore, prior introducing the radiopharmaceutical in the clinical routine, we decided to produce a small kit batch. After the preparation of frozen kits, which were found sterile, their storage stability on $-20^{\circ} \mathrm{C}$ was tested within the period of 6 months. Protocol 2 was used for the radiolabeling, after adding $0,2 \mathrm{~N}$ phosphate buffer to the mixture. The labeling yield during period observed (expressed as mean of duplicate assessment) is displayed on Fig. 3. The range of the ra- diolabeling yield was between $94,3 \%$ and $96,9 \%$. After 6 months, no decrease of radiolabeling yield was observed.

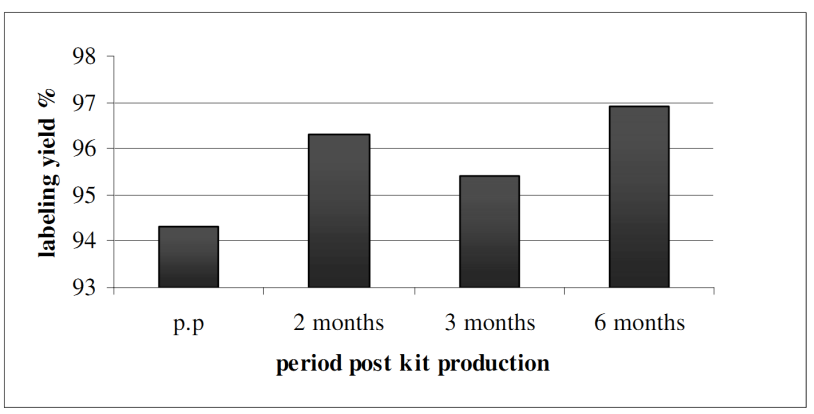

Fig. 3. Storage stability of the frozen kit formulation up to 6 months post production (p.p.= immediately post production)

a)

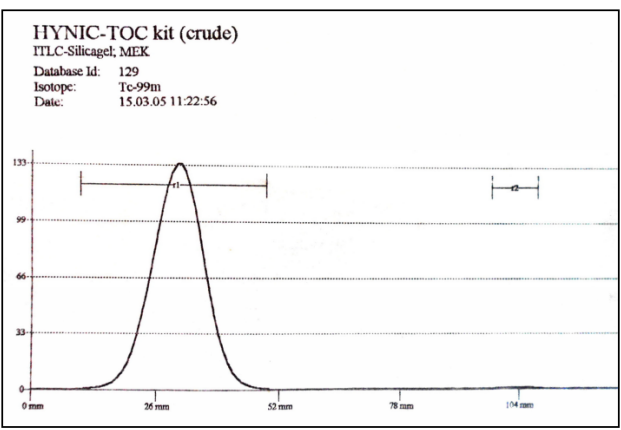

b)

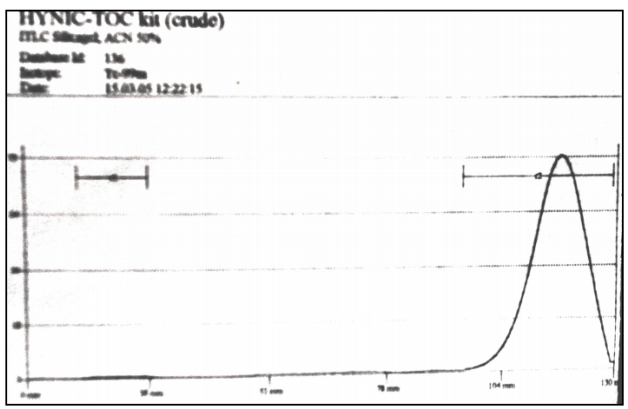

c)

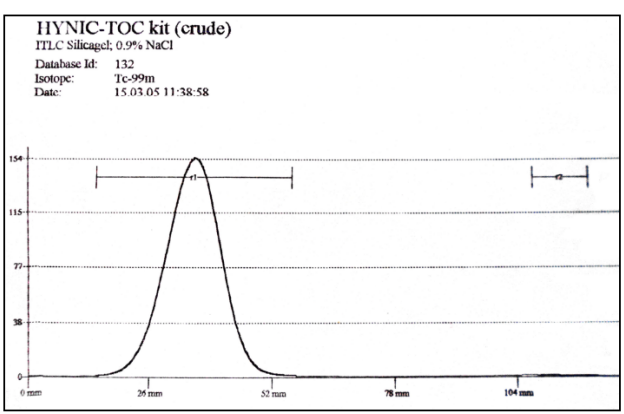

Fig. 4. Radiochromatograms (ITLC) of ${ }^{99 \mathrm{~m}} \mathrm{Tc}-\mathrm{EDDA} /$ HYNIC-TOC kit after 6 months storage at $-20{ }^{\circ} \mathrm{C}$ : a) $\operatorname{MEK}(\mathrm{Rf}=1)$ free ${ }^{99 \mathrm{~m}} \mathrm{Tc}-$ pertechnetate; b) $50 \%$ ACN ( $\mathrm{Rf}=0){ }^{99 \mathrm{~m}} \mathrm{Tc}$-coloid; c) $0.9 \% \mathrm{NaCl}(\mathrm{Rf}=1)$ ${ }^{99 \mathrm{~m}} \mathrm{Tc}-$ non peptide bound coligand + free ${ }^{99 \mathrm{~m}} \mathrm{Tc}-$ pertechnetate

Maced. pharm. bull., $57(1,2) 65$ - 70 (2011) 
The radiochromatograms obtained from the ITLC strips for the three main radiochemical impurities (Fig. 4.) illustrate the good quality of our radiopharmaceutical and indicate that frozen kit can be a safe alternative to the freeze-dried for small batch in house production.

We could not compare our stability findings with those published in the literature available, because they are mainly related to the in house wet labeling procedures (Melero et al., 2009; Pusuwan et al., 2010) or in house freeze dried kits (von Guggenberg et al., 2004; Gandomkar et al., 2006; Tasdelen, 2011). In house production of ${ }^{99 \mathrm{~m} T c-E D-}$ DA/HYNIC-TOC is usually carried out within Coordinated Research Projects or Technical Cooperation Projects of IAEA in labs worldwide due to its restricted availability. The only commercially released kit so far is Tektrotyd from Radioisotope Centre POLATOM, Poland.

\section{Conclusion}

In house kit production, performed in compliance with GMP and GRP regulations within hospital premises is sometimes the only way to introduce novel radiopharmaceuticas, especially in developing countries. Following the proscribed and optimized procedures, we produced ${ }^{99 \mathrm{~m}}$ Tc-EDDA/HYNIC-TOC, a specific SST receptor targeting agent which fulfilled the quality control criteria for radiochemical purity, sterility, normal biodistribution and stability. Our future activities will be focused on the clinical application and evaluation on selected group of patients.

\section{Acknowledgements}

This work was supported by IAEA Technical Co-operation Project MAK3/004 'Developing of 99mTc labeled peptides and monoclonal antibodies".

We wish to thank C. Decristophoro and E. von Guggenberg from the University Clinic for Nuclear Medicine, Innsbruck, Austria for sharing their experience in EDDA/ HYNIC-TOC labeling, and preclinical and clinical evaluation of the radiopharmaceutical.

\section{References}

Bangard, M., Behe, M., Guhlke, S., Otte, R., Bende,r H., Maecke, H.R., Bierscack, H.J., 2000. Detection of somatostatin receptor-positive tumors using the new ${ }^{99 \mathrm{~m} T c-t r i c i n e-}$ Hynic-D-Phe ${ }^{1}-$ Tyr $^{3}$-octreotide: First results in patients and comparison with ${ }^{111}$ In-DTPA-D-Phe ${ }^{1}$-octreotid. Eur. J. Nucl. Med. 27, 628-637.

Decristoforo, C., Mather, S.J., Cholewinski, W., Donnemiller, E., Riccabon,a G., Monkayo, R., 2000. 99mTc-EDDA/HYNICTOC: a new $99 \mathrm{mTc}$-labelled radiopharmaceutical for imaging somatostatine receptor -positive tumors: first clinical results and intra-patient comparison with 111In-labelled octreotide derivatives.,Eur. J. Nucl. Med. 9, 1318-1325.

Decristoforo, C., Mather, S.J., 1999. Technetium-99m somatostatin analogues effect of labeling methods and peptide sequence. Eur. J. Nucl. Med. 26, 869-876.

Gandomkar, M., Najafi, R., Babaci, M.H., Shafei, M., Sadat, Ebrahimi S.E., 2006. Synthesis, development and preclinical comparison of two new peptide based freeze-dried kit formulation 99mTc-EDDA-TRICINE-HYNIC-TOC and 99mTc-EDDA-TRICINE-HYNIC-TATE for somatostatin receptor positive tumor scintigraphy. DARU. 14, 183-189.

Krennung, E.P., Kwekkeboom, D.J., Bakker, W.H., Breeman, W.A., Kooij, P.P., Oei, H.Y., van Hangen, M., Postema, P.T., de Jong, M., Reubi, J.C.,1993. Somatostatin receptor scintigraphy with $\left[{ }^{111} \mathrm{In}_{-\mathrm{DTPA}}{ }_{\mathrm{D}}-\mathrm{Phe}\right]$ and [123I-tyr]octreotide: the Rotterdam experience with more than 1000 patients. Eu.r J. Nuc.1 Med. 20, 716-731.

Lebtahi, R., Cadiot, G., Sarda, L., Daou, D., Fa-raggi, M., Petegnief, Y., Mignon, M., le Guludec, D.,1997. Clinical impact of somatostatin receptor scintigraphy in the management of patients with neuroendocrine gastroenteropancreatic tumors. J. Nucl. Med. 38, 853-858.

Liu, S., Edwards, D.S., Barrett, J.A.,1997. 99mTc Labeling of highly potent small peptides. Biconjugate Chem. 8, 621636.

Maina, T., Stolz, B., Albert, R., Nock, B., Bruns, C., Macke H.,1995. Synthesis, radiochemistry and biological evaluation of $99 \mathrm{mTc}\left[\mathrm{N}_{4(\mathrm{D})} \mathrm{PHE}_{1}\right]$-octreotide, a new octreotide derivative with high affinity for somatostatin receptors. In: Nicolini M, Bandoli G, Mazzi U, eds. Technetium and rhenium in chemistry and nuclear medicine 4. Padova: SG Editoriali: 395-400.

Melero, L.T.U.H., Araujo, E.B., Mengatti, J., 2009. Radiolabeling, quality control and radiochemical purity assessment of 99mTc-HYNIC-TOC. International Nuclear Atlantic Conference INAC 2009, Rio de Janeiro, RJ, Brazil, September 27 to October 2, 2009.

Plachcinska, A., Mikolajczak, R., Maecke, H.R., Mlodkowska, E., Kunert-Radek, J., Michalski, A., Rzeszutek, K., Kozak, J., Kusmierk, J.,2003. Clinical usefulness of 99mTc-EDDA/ HYNIC-TOC scintigraphy in oncological diagnostic: a preliminary communication. Eur. J. Nucl. Med. Mol. Imaging. 30,1402-1406.

Plachcinska, A., Mikolajczak, R., Maecke, H.R., Mlodkowska, E., Kunert-Radek, J., Michalsk,i A., Rzeszutek, K., Kozak, J., Kusmierk, J., 2004. Clinical usefulness of 99mTc-EDDA/ HYNIC-TOC scintigraphy in oncological diagnostic: a pilot study. Biotherapy \& Radiopharmaceuticals. 19, 261-270.

Pursuwan, P., Tocharoenchai, C., Sriussadaporn, S., Muangsomboon, K., Poramatiku,1 N., Tiparoj, R., 2010. Somatostatin receptor scintigraphy in localization of pancreatic neuroendocrine tumors: a preliminary study. Siriraj Med. J. 62, 53-56.

Shi, W., Johnston, C.F., Buchnan, K.D., Ferguson, W.R., Laird, J.D., Grotes, J.G., McIlrath, E.M.,1998. Localization of neuroendocrine tumors with [111In]DTPA-octreotide scintigraphy (Octreoscan): a comparative study with CT and MR imaging. Q. J. Med. 91, 295-301.

Tasdelen, B., 2011. The effect of selected preparation variables on the radiochemical purity of 99mTc-EDDA-HYNIC-TOC. J. Radioanal. Nucl. Chem. 287, 491-495.

Vallabhajosula, S., Moyer, B.R., Lister-James, J., McBrrrride, B.J., Lipszyk, H., Lee, H., Bastidas, D., Dean, R.T.,1996. Preclinical evaluation of technetium - $99 \mathrm{~m}$-labeled somatostatin receptor binding peptides. J. Nucl. Med. 37, 1016-1022. 
Von Guggenberg, E., Mikolajczak, R., Janota, B., Ricabona, G., Decristoforo, C., 2004. Radiopharmaceutical development of freeze-dried kit formulation for the preparation of $\left[{ }^{99} \mathrm{Tc}-\right.$ EDDA/HYNIC-D-Phe ${ }^{1}, \mathrm{Tyr}^{3}$ ]-Octreotide, a somatostatin analog for tumor diagnosis. J. Pharm. Sci. 93. 2497-2506.
Von Guggenberg, E., Sarg, B., Lidner, H., Melendez Alafort, L., Mathe,r S.J., Monkayo, R., Decristoforo, C., 2003. Preparation via coligand exchange and characterization of [99mTc-EDDAHYNIC-D-Phe ${ }^{1}$, Tyr ${ }^{3}$ Octreotide (99mTc-EDDA/HYNICTOC). J. Label. Compd. Radiopharm. 46, 307-318.

Резиме

\title{
"In house" производство на ${ }^{99 \mathrm{~m}}$ Tc-EDDA/HYNIC- TOC, специфичен насочувачки агенс за соматостатин - рецепторна сцинтиграфија
}

\author{
Соња Кузмановска, Оливија Васкова, Марина Здравеска Кочовска
}

\begin{abstract}
Институт за патофизиологија и нуклеарна медицина, Медицински факултет, Универзитет „Св. Кирил и Методиј”, Водњанска 17, Скопје, Република Македонија
\end{abstract}

Клучни зборови: радиофармацевтик, технециум-99m, тир3-октреотид, рецепторна сцинтиграфија, домашно производство, контрола на квалитет.

Употребата на радиообележени пептидни лиганди како дијагностици и терапевтици во нуклеарната онкологија е зголемена во последно време. Еден од најчесто користените радиофармацевтици е ${ }^{99 \mathrm{~m}} \mathrm{Tc}-\mathrm{EDDA} / \mathrm{HYNIC-TOC,} \mathrm{соматостатински} \mathrm{аналог} \mathrm{кој} \mathrm{спе-}$ цифично се врзува за одредени типови соматостатински рецептори со висок дензитет кај тумори од невроендокрино потекло. Радиофармацевтикот не е широко комерцијално достапен и поради тоа го воведовме како „in house“ производ, како дел од проект поддржан од Меѓународната агенција за атомска енергија (МААЕ). Во рамките на процедурите за предклиничка проценка, оптимизиран е протоколот за радиообележување, произведена е мала серија китови, извршена е контрола на квалитет со инстант тенкослојна хроматографија и се направени биодистрибуциони студии. Процесот на радиообележување на пептидот, изведен со измена на ко-лиганди на температура од $100{ }^{\circ} \mathrm{C}$ за време од 10 мин., резултираше со радиохемиска чистота $>90 \%$. Биодистрибуционите сцинтиграми кај нормални Wistar стаорци покажаа брз клиренс од циркулацијата по 15 мин. и доминантна акумулација во бубрезите по 4 часа, што е во согласност со податоците објавени од други автори. Беше проценета стабилноста на препаратот, произведен во мала серија, на $-20^{\circ} \mathrm{C}$ при складирање за време од 6 месеци, при што ефикасноста на радиообележување се движеше од 94,3\% до 96,9\%. Нашите резултати покажаа дека смрзнатите китови можат да бидат сигурна алтернатива на лиофилизираните, во услови на домашно производство на мали серии, а по задоволителната предклиничка проценка ${ }^{99 \mathrm{~m} T c-E D D A / H Y N I C-T O C}$ може да биде воведен во клиничката практика како специфичен насочувачки агенс за соматостатин - рецепторна сцинтиграфија. 